\title{
Maturation curves of sweet sorghum genotypes
}

\section{Curvas de maturação de genótipos de sorgo sacarino}

\author{
Renan Silva e Souza ${ }^{1 *}$, Rafael Augusto da Costa Parrella², \\ Vander Fillipe de Souza ${ }^{3}$, Nádia Nardely Lacerda Durães Parrella ${ }^{1}$
}

\author{
'Universidade Federal de São João del-Rei/UFSJ, Departamento de Ciências Agrárias, Sete Lagoas, MG, Brasil \\ ¿Empresa Brasileira de Pesquisa Agropecuária/Embrapa Milho e Sorgo, Sete Lagoas, MG, Brasil \\ 3Universidade Federal de São João del-Rei/UFSJ, Departamento de Engenharia de Biossistemas, São João del-Rei, MG, Brasil \\ *Corresponding autor: renan@ualberta.ca \\ Received in june 15, 2015 and approved in september 10, 2015
}

\begin{abstract}
Sweet sorghum [Sorghum bicolor (L.) Moench] stands out as a complementary crop to sugarcane Saccharum spp. for the production of ethanol, since it has juicy stems with directly fermentable sugars. Due to this fact, there is a need for the analysis of sweet sorghum properties in order to meet the agro-industry demand. This work aimed to develop and study the maturation curves of seven sweet sorghum cultivars in ten harvest dates. The results showed a significant difference between cultivars and harvest dates for all parameters analysed $(p \leq 0.01)$. Regarding the sugar content, the cultivars BRS508, XBWS80147 and CMSX629 showed the highest means for the total reducing sugars (TRS) and recoverable sugar (RS). In the production of ethanol per tonne of biomass (EP), the cultivars BRS508 and CMSX629 presented the best results.
\end{abstract}

Index terms: Ethanol; reducing sugars; period of industrial use.

\section{RESUMO}

O sorgo sacarino [Sorghum bicolor (L.) Moench] se destaca como cultura complementar à cana-de-açúcar Saccharum spp. na produção de etanol, uma vez que este possui colmos suculentos com presença de açúcares diretamente fermentescíveis. Em decorrência deste fato, existe a necessidade de se analisar as propriedades do sorgo, a fim de atender às demandas da agroindústria. No presente trabalho, buscou-se desenvolver e estudar as curvas de maturação de sete cultivares de sorgo sacarino em dez épocas de colheita. Os resultados mostram que houve diferença significativa para cultivares e épocas de colheita para todos os parâmetros ( $\leq \leq 0,01)$. Quanto aos teores de açúcares, as cultivares BRS508, XBWS80147 e CMSXS629 apresentaram as maiores médias para as variáveis açúcares redutores totais (ART) e açúcares totais recuperáveis (ATR). Em relação à produção de etanol por tonelada de biomassa, as cultivares BRS 508 e a CMSXS629 apresentaram os melhores resultados.

Termos para indexação: Etanol; açucares redutores; periodo de utilização industrial.

\section{INTRODUCTION}

The growing demand for energy and the intensive exploration of fossil fuels reserves bring us to a reflection about the need for diversification of the worldwide energy matrix. According to Tomaz and Assis (2013), uncertainty about the availability of non-renewable resources in the future and geopolitical tension in oil producing regions is creating a growing interest in biofuels, due to the fact that these fuels can supply part of the demand for energy in a long term period. Furthermore, as a result of public awareness and knowledge about climate change, there is a need for finding energy sources that do not cause negative impacts on the environment and have lower production cost (Zegada-Lizarazu; Monti, 2012).
Sugarcane (Saccharum spp.) is a crop well developed for the production of biofuel. According to a survey by the National Supply Company of Brazil-Conab, in the 2014/2015 season, the cultivated area corresponded to approximately 9.098 million hectares. The total production of sugarcane was estimated in 659.1 million tonnes with an average yield of 74.769 t. ha-1 (Conab, 2014). Despite the fact that sugarcane exhibit high yields, the crop has an offseason period that causes inactivity in the ethanol plants. Additionally, the availability of water tends to become a major constraint to agricultural production in the next years (Ryan; Spencer, 2001), thereby the cultivation of sugarcane may become difficult in some regions, since this crop has a high water requirement (Dayakar et al., 2004). In this scenario, sweet sorghum 
Sorghum bicolor (L.) Moench would become a logical option to complement the production system.

Sweet sorghum is characterized by high photosynthetic efficiency and energy production capacity similar to sugarcane with satisfactory production of fresh mass and juicy stems with high levels of fermentable sugars (May et al., 2012a). Due to this production of sugars, sweet sorghum is considered an energy crop of particular importance for the production of ethanol (Gnansounou; Dauriat; Wyman, 2005; Worley; Vaughan; Cundiff, 1992).

Compared to other energy crops, sorghum shows a wider adaptability to different environments and soil conditions. When compared to maize, sorghum is more tolerant to drought and it is more efficient in water and nutrients usage. In comparison to sugarcane, it has a shorter growth cycle and it is propagated by seeds which facilitates planting operations (Guiying, 2000; Prasad, 2007).

One of the obstacles to this crop is the fact that sugarcane has established dominance over the production chain of sugar and ethanol, receiving the majority of the investments. However, sweet sorghum is rapidly expanding and has a great potential for further growth. In countries like China, India, United States, Brazil, Iran, Italy and Spain, this crop is considered a promising feedstock for ethanol production, and many research projects have been developed with it in these countries (Almodares; Hadi; Ahmadpour, 2008; Channappagoudar et al., 2007; Wortmann et al., 2010).

Even though this plant has a great adaptability, we must remember that in order to exploit the full potential of the crop, it is necessary to provide suitable conditions for its development. According to May et al. (2012a), contrary to what is long believed, in order to obtain satisfactory yields, sweet sorghum needs development conditions similar to other crops, as the adequate soil preparation, fertilization and control of insects, diseases and weeds.

In Brazil, Embrapa (Brazilian Corporation of Agricultural Research) began a program for the development of sweet sorghum cultivars in the 1970s. Initially, 50 genotypes of the United States Department of Agriculture (USDA), Africa and India, were introduced and had its agronomic traits assessed. However, with the poor success of Proálcool, the national ethanol program, and the national policy directed to large ethanol plants, the focus of research on sweet sorghum was redirected to the production of fodder (Parrella, 2011).

Currently sweet sorghum is being included in the ethanol industry with the proposal of providing feedstock additionally to sugarcane, with the main objective of anticipating the harvest, being processed in the mills in March and April, reducing the need for sugarcane in a period of low quality of its juice. Therefore, sorghum seeds should be sown preferably in November or December of the previous year, since the cycle of the species is from 120 to 150 days (May et al., 2012b).

Unlike sugarcane, sweet sorghum starts the accumulation of sugars in the stem in its reproductive stage, mainly on the physiological maturity of the grains (Teixeira et al. 1999). Due to this difference, the evaluation of the sugar accumulation profile in the stem is an important factor in determining the potential use of each cultivar. This assessment can be done through the study of the period of industrial use (PIU) required for the harvest planning and processing of the material, which should be the longest possible, with a minimum threshold of 30 days.

The PIU comprehends the period in which the cultivar can stay on the field maintaining productivity and quality at optimal levels, according to the minimum standards established to ensure the viability of the crop until it is harvested and processed by the ethanol plant. In this context, this study aimed to establish the maturation curves of seven cultivars of sweet sorghum, by analyzing the sugar accumulation profile in the stem over time, in order to determine the PIU and the ethanol yield of each genotype throughout the evaluation period.

\section{MATERIAL AND METHODS}

During the season of 2013-2014, comparative trials of sweet sorghum cultivars were conducted in an experimental area of Embrapa Miho e Sorgo in Sete Lagoas

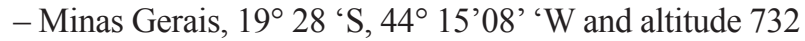
$\mathrm{m}$. The climate in the region is Aw (Köppen), typical of savannah, with dry winter and average temperature of the coldest month above $18^{\circ} \mathrm{C}$. The soil of the area is classified as ferralsols whose characteristics are shown in Table 1. In the seeding operation, $400 \mathrm{~kg} \mathrm{ha}^{-1}$ of 8-28-16 (NPK) were applied, and $200 \mathrm{~kg} \mathrm{ha}^{-1}$ of urea were used in topdressing 20 days after sowing. After 15 days of emergence, roughing was performed in order to keep eight plants per linear meter, totaling 40 plants per rows of five meters.

The weed control was performed with Atrazine, at a dose of $1.5 \mathrm{~kg}$ of active ingredient per hectare and it was complemented by manual weeding. Supplementary irrigation was applied during crop establishment to avoid water deficit. The genotypes used in this work were BRS508 and BRS511 (commercial varieties of Embrapa), XBWS80147 and XBWS80007 (Commercial Hybrids of Monsanto), two experimental genotypes of Embrapa (CMSXS647, CMSXS629) and the Sugargraze (commercial Hybrid of Advanta). 
The seven genotypes were evaluated in an experiment designed in randomized block with three replications and the sowing performed on 15 of October 2013. The experimental plot consisted of three rows of $5 \mathrm{~m}$ long with $0.70 \mathrm{~m}$ of spacing with a population of 114,000 plants ha ${ }^{-1}$. Only the central row was considered to perform the evaluation. The plots were harvested sequentially starting from the flowering stage, 93 days after sowing, considering that the genotypes had similar flowering patterns. In total, ten harvests were performed with an interval of seven days, following the schedule shown in Table 2. During the harvests, the evaluations were focused on the fresh mass production (FMP) in $\mathrm{tha}^{-1}$, the percentage of total reducing sugars (TRS) in \% of juice, the recoverable sugars (RS) in $\mathrm{kg}$ of sugar per tonne of biomass and the ethanol production in liters per tonne of biomass (EP).

The fresh mass production was calculated in the plot and transformed into tonnes per hectare. The plants were harvested at $5.0 \mathrm{~cm}$ from the soil surface. After removing the panicles, the stalks with leaves were weighed using a digital scale. Samples of eight stalks without leaves were collected in each plot and then fragmented and homogenized in appropriate equipment. Subsamples of
500 grams of the material were pressed using a hydraulic press ( $245 \mathrm{~kg} \mathrm{~cm}^{-2}$ for 60 seconds) for the juice extraction.

The juice extracted from the stalks was analysed in the saccharimeter for determination of sucrose and Redutec $\AA$ for determination of reducing sugars. For the calculation of the variables analyzed in this work, the following formulas adapted from Conselho dos Produtores de Cana-De-Açúcar e Álcool do Estado de São PauloConsecana (2006), were used:

- Total reducing sugars extracted from the juice (TRS) - (\% of reducing sugars in the juice):

TRS $=\%$ reducing sugars $+P o l / 0.95$

$\mathrm{Pol}=$ Apparent content of sucrose

- Recoverable sugar (RS) - (kg of recoverable sugar per tonne of biomass):

$10 \times \mathrm{PC}=$ Pol per tonne of biomass

$1.05263=$ stoichiometric coefficient of conversion of sucrose into reducing sugars

Table 1: Soil analysis of the experimental area - EMBRAPA Milho e Sorgo CNPMS - Sete Lagoas/MG.

\begin{tabular}{|c|c|c|c|c|c|c|c|c|c|c|c|c|c|}
\hline \multirow{2}{*}{ Sample } & $\mathrm{pH}$ & M. O. & $P$ & K & $\mathrm{Ca}$ & $\mathrm{Mg}$ & $\mathrm{Al}$ & $\mathrm{H}+\mathrm{Al}$ & SB & CTC & C & V & Sat. Al \\
\hline & $\mathrm{H}_{2} \mathrm{O}$ & (dag/kg) & \multicolumn{2}{|c|}{$\left(\mathrm{mg} / \mathrm{dm}^{3}\right)$} & \multicolumn{6}{|c|}{$\ldots$} & \multicolumn{3}{|c|}{..............(\%)................ } \\
\hline $00-20 \mathrm{~cm}$ & 6 & 5.3 & 15.0 & 246.7 & 9.1 & 0.8 & 0.04 & 7.4 & 10.6 & 17.9 & 3.0 & 59 & 0.38 \\
\hline $20-40 \mathrm{~cm}$ & 6.1 & 4.6 & 14.2 & 206.9 & 8.9 & 0.8 & 0.05 & 7.4 & 10.3 & 17.7 & 2.7 & 58 & 0.48 \\
\hline
\end{tabular}

$\mathrm{PH}$ in distilled water; Extractor of P, K and micronutrients, Mehlich-1; M.O - Organic Matter; Cation-exchange capacity - S+H+Al; $\mathrm{V}$ - Percent Base Saturation - V=100 S/T.

Table 2: Harvest schedule of the experimental plots.

\begin{tabular}{ccc}
\hline Operation & Date & Days of Plant Development \\
\hline Seeding & October 15, 2013 & 0 \\
1st Harvest & January 16, 2014 & 93 \\
2nd Harvest & January 23, 2014 & 100 \\
3rd Harvest & January 30, 2014 & 107 \\
4th Harvest & February 06, 2014 & 114 \\
5th Harvest & February 13, 2014 & 121 \\
6th Harvest & February 20, 2014 & 128 \\
7th Harvest & February 27, 2014 & 135 \\
8th Harvest & March 06, 2014 & 142 \\
9th Harvest & March 13, 2014 & 149 \\
10th Harvest & March 20, 2014 & 156 \\
\hline
\end{tabular}


$0.905=$ coefficient of recovery for an industrial loss of $9.5 \%$ $10 \times \mathrm{RST}=$ reducing sugars per tonne of biomass

- Hydrated Ethanol Production Estimation (EP) (liters of ethanol per tonne of biomass):

$E P=T R S \times 10 \times 0.6475^{*}$

*Considering a fermentation process of $85 \%$ efficiency.

The collected data were subjected to a combined analysis of variance in factorial design, with seven genotypes $x$ ten harvests, using the software Genes ${ }^{\circledR}($ Cruz, 2006). In addition, regression curves were generated for each genotype to evaluate the sequence of physical and chemical changes that occurred during the maturation, as well to monitor the formation of sugars in the stalks of the plant in order to find the best moment for harvesting. To build the curves, it was used the fresh mass production (FMP), total reducing sugars (TRS), recoverable sugars (RS) and an estimated production of ethanol in liters per tonne of biomass (EP).

The parameters used for the determination of the period of industrial use (PIU) used in this work were the minimum levels of sugars, corresponding to $12.5 \%$ for total reducing sugars (TRS) and $80 \mathrm{~kg} \mathrm{t}^{-1}$ for recoverable sugars (RS) (May et al., 2012a; Schaffert, 2011).

\section{RESULTS AND DISCUSSION}

\section{Statistical analysis}

The analysis of variance for fresh mass production (FMP), total reducing sugars (TRS), recoverable sugars
(RS) and ethanol production (EP) is shown in Table 3. A significant difference was identified for cultivars and harvest day for all characteristics $(\mathrm{p} \leq 0.01)$. This fact demonstrates the genetic differences between cultivars and the influence of the harvest time over the potential yields, indicating the different physiological development profile of the plants during the evaluations. On the interaction between cultivars and harvest day, no significant differences were observed for FMP, which shows that changes in the performance ranking or in the magnitude of the differences between of cultivars did not occur during the evaluations of this characteristic.

On the other hand, in this same source of variation, there was a significant difference at $5 \%$ probability for the TRS, RS and EP. This fact shows that the cultivars had different responses to the interaction between their genotype and the moment of the harvest. It further indicates that the cultivars have distinct profiles of formation and concentration of non-structural carbohydrates in the stalk. The coefficient of variation of the data, for all characteristics (FMP - 13.58\%, TRS - 9.79\%, RS - 9.18\% and EP - 9.79\%) were satisfactorily low, showing that the experiment had acceptable errors for the study of these characteristics.

\section{Fresh mass production (FMP)}

The fresh mass production is a key factor for the production of ethanol and there is a strong association between fresh mass production and the ethanol yield per hectare because the sugar-rich juice is extracted entirety from this biomass (Murray et al., 2008; Ritter et al., 2008). Therefore, the higher the production of fresh mass, the greater will be the quantity of juice and sugar per hectare and consequently a higher volume of ethanol.

Table 3: Combined analysis of variance for Fresh Mass Production (FMP) in $\mathrm{t} \mathrm{ha}^{-1}$, total reducing sugars (TRS), in $\%$, recoverable sugars (RS) in $\mathrm{kg} \mathrm{t}^{-1}$, and ethanol production (EP), in liters per tonne of seven cultivars of sweet sorghum in ten harvest dates after flowering (93 days after sowing).

\begin{tabular}{|c|c|c|c|c|c|c|c|c|c|}
\hline \multirow{2}{*}{$\begin{array}{l}\text { Source of } \\
\text { Variation }\end{array}$} & \multicolumn{9}{|c|}{ MS } \\
\hline & $\mathrm{DF}$ & FMP & & TRS & & $\mathrm{RS}$ & & EP & \\
\hline Block/Harv. day & 20 & 164.46 & & 1.56 & & 106.52 & & 47.27 & \\
\hline Cultivars (C) & 6 & 2627.98 & $\star \star$ & 51.14 & $\star *$ & 2510.17 & $\star *$ & 1549.23 & ** \\
\hline Harv. day $(\mathrm{H})$ & 9 & 1581.67 & $\star \star$ & 92.32 & $\star \star$ & 4744.89 & $\star \star$ & 2796.22 & $\star \star$ \\
\hline $\mathrm{C} \times \mathrm{H}$ & 54 & 90.92 & NS & 1.64 & * & 90.39 & * & 49.84 & * \\
\hline Residual & 120 & 92.72 & & 1.05 & & 55.51 & & 31.88 & \\
\hline Mean & & 70.91 & & 10.47 & & 81.16 & & 57.63 & \\
\hline CV(\%) & & 13.58 & & 9.79 & & 9.18 & & 9.79 & \\
\hline
\end{tabular}

*, ** significant on F-test at $5 \%$ and $1 \%$ probability, respectively. 
The regression curves corresponding to the fresh mass production (FMP) of the genotypes (Figure 1) show initial values between about 70 and $100 \mathrm{tha}^{-1}$, with emphasis on CMSXS647, XBWS80147 and XBWS80007 with total average yield of $88.74 \mathrm{t} \mathrm{ha}^{-1}, 75.18 \mathrm{t} \mathrm{ha}^{-1}$ and $70.51 \mathrm{t} \mathrm{ha}^{-1}$, respectively. The other genotypes showed an average yield between $60 \mathrm{tha}^{-1}$ and $70 \mathrm{tha}^{-1}$. These results show the potential for biomass production of sweet sorghum compared to sugarcane which has an average yield of $74.769 \mathrm{t} \mathrm{ha}^{-1}$ (Conab, 2014).

In a study conducted by Albuquerque et al. (2012) where two cultivars (BRS506 and BRS507) were compared in different row spacing and densities in the state of Minas Gerais in Brazil, it was possible to reach yields between $36.44 \mathrm{tha}^{-1}$ and $45,75 \mathrm{tha}^{-1}$ of fresh mass, values lower than those indicated in the present work. In contrast, May et al. (2012b) also evaluating the potential of sweet sorghum in different settings for the production of ethanol, reached higher values, with yields of $80.61 \mathrm{t}$ $\mathrm{ha}^{-1}$ in the central region of Minas Gerais.

In the analysis of the curves in Figure 1, it is possible to note a remarkable performance of the experimental line CMSXS647, which had the highest production in all harvests. Despite the fact that this genotype had the lowest coefficient of determination, it is clear that this material has a great potential for further use in sweet sorghum breeding programs.

The high yield of fresh biomass is an important indicator of the potential of sweet sorghum, but it alone does not provide the necessary requirements for the qualification of cultivars when the objective is the ethanol production. Therefore, it is necessary to evaluate the sugar accumulation curves during the plant development.

\section{Total reducing sugars (TRS)}

The reducing sugars are monosaccharides able to be oxidized in the presence of oxidizing agents in alkaline solutions, since they have free carbonyl and ketone group (Silva, 2003). In this study, the reducing sugars considered were glucose and fructose.

The total reducing sugars are the result of the sum of reducing sugars themselves, contained in the sorghum juice, and the glucose and fructose originated from the hydrolysis of sucrose. They are represented by all sugars in the material in the form of inverted sugar and make up all the sugar (sucrose + glucose + fructose) in the juice, expressed in percentage (Fernandes, 2011). The reducing sugars represent a quality parameter of the feedstock widely used by the sugar and ethanol industry. Usually the cultivars that have high content of sugars and low fibers are more susceptible to physical damage and attack of pests and microorganisms.

Fresh Mass Production (FMP)

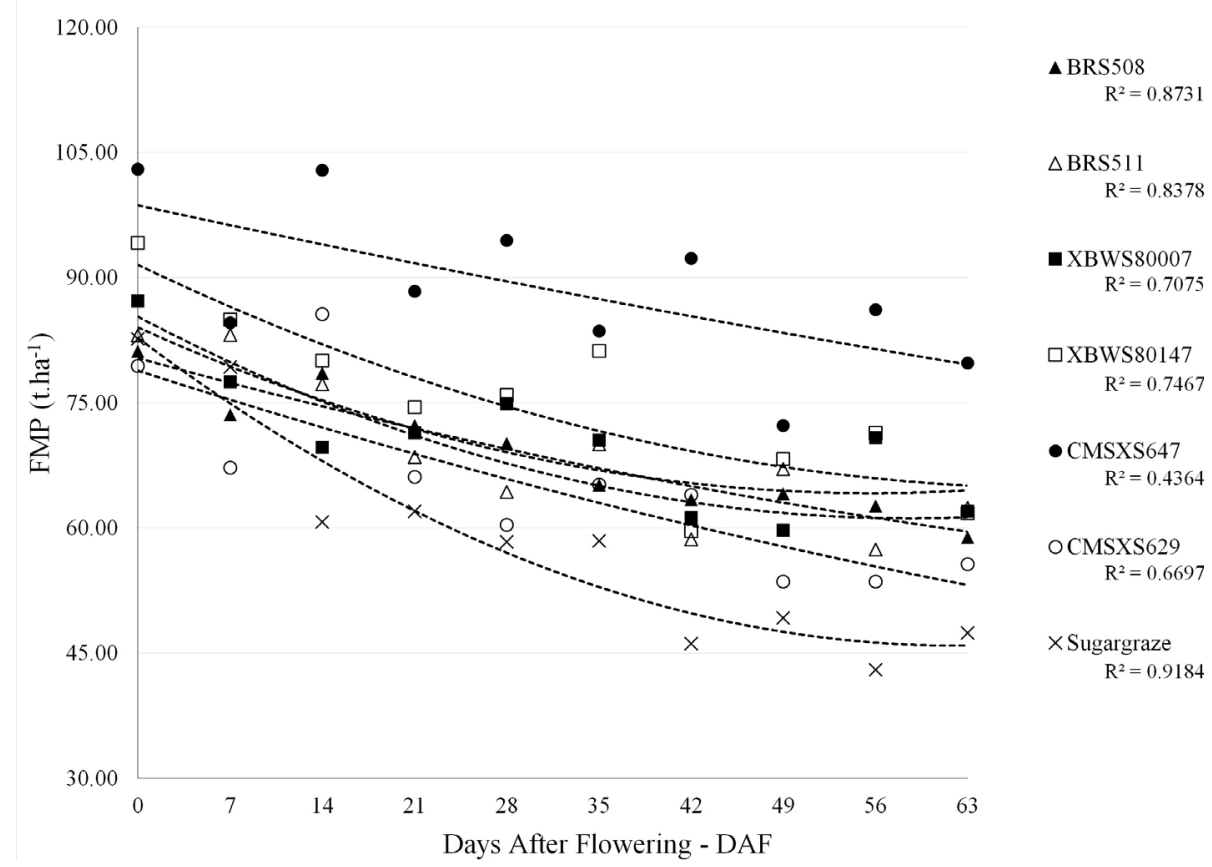

Figure 1: Curves of Fresh Mass Production (FMP) in $\mathrm{t} \mathrm{ha}^{-1}$ of seven cultivars of sweet sorghum in ten harvest dates. 
The Figure 2 shows the performance of the cultivars regarding the accumulation of total reducing sugars (TRS). The cultivar BRS508 had the highest means for total reducing sugars in all harvests, with values higher than the established minimum starting from 28 days after flowering and keeping the high content until the end of the evaluations, totaling 35 days.

The cultivar XBSW80147 reached a sugar level above the established minimum after 42 days and maintained it for 21 days. The cultivar CMSXS629 also reached the minimum value of TRS after 42 days, keeping it for 14 days and decreasing to a value lower than the established minimum in the last evaluation. The other cultivars did not reach the minimum threshold for TRS. This fact may be related to the occurrence of sugarcane borer Diatrea sacchralis in some of the plots and the consequent red rot in the stalk caused by the fungus Colletotrichum falcatum and Fusarium moniliforme.

\section{Recoverable sugars (RS)}

The recoverable sugars correspond to the amount of total sugars extracted from the juice (Fernandes, 2011; Consecana, 2006). Currently, the payment to growers is based in kilograms of total recoverable sugars (RS), as established by the Conselho dos Produtores de Canade-Açúcar e Álcool do Estado de São Paulo-Consecana Among the advantages of this payment method, there is the quality of the feedstock because the grower seeking better earnings, deliver a better quality material, not only focusing on yield per hectare (Consecana, 2006).

As can be seen in Figure 3, the maturation curves of recoverable sugars resemble the TRS. Analysing these curves, it is possible to evaluate the period of industrial use (PIU), which comprises the cultivating period for which the RS is at or above $80 \mathrm{~kg} \mathrm{t}^{-1}$. It is recommended a PIU of at least 30 days to ensure a good planning and processing of the feedstock. The RS in the cultivars BRS508 and CMSXS629 were above the established minimum starting from the third evaluation (14 DAF), totaling approximately 50 days of PIU, with and average value of $98.87 \mathrm{~kg} \mathrm{t}^{-1}$ and $86.11 \mathrm{~kg} \mathrm{t}^{-1}$ and the highest value of $122.78 \mathrm{~kg} \mathrm{t}^{-1} 104.49 \mathrm{~kg} \mathrm{t}^{-1}$ at $42 \mathrm{DAF}$, respectively. The cultivars XBSW80147 and XBWS80007 reached the minimum threshold at 21 and 28 days after flowering, totaling approximately 42 and 35 days of PIU, with average production of $80.38 \mathrm{~kg} \mathrm{t}^{-1}$ and $75.89 \mathrm{~kg} \mathrm{t}^{-1}$ and highest of $99.07 \mathrm{~kg} \mathrm{t}^{-1}$ and $93.70 \mathrm{~kg} \mathrm{t}^{-1}$ at $42 \mathrm{DAF}$, respectively.

The cultivars BRS511 and Sugargraze reached the minimum value after 35 days, maintaining a PIU of 28 days

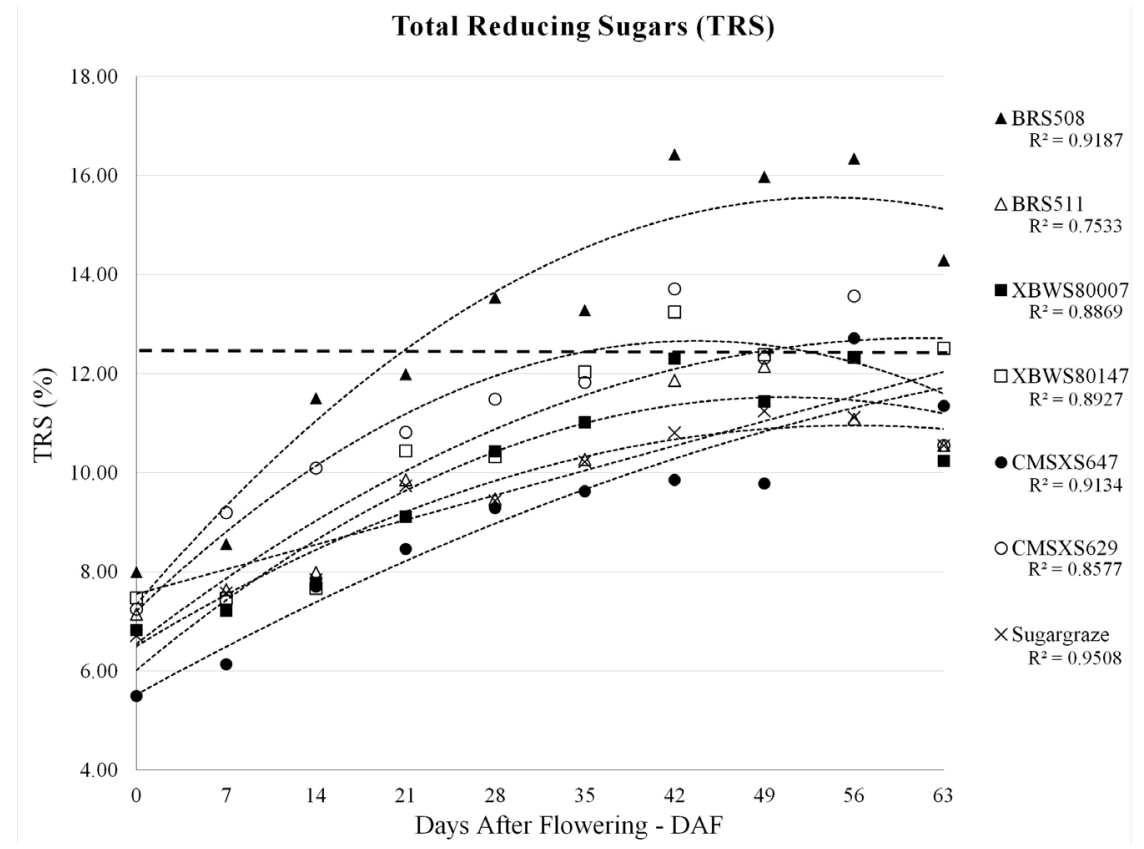

Figure 2: Curves of total reducing sugars (TRS), in \% of extracted juice of seven cultivars of sweet sorghum in ten harvest dates. 
and an average yield of $77.60 \mathrm{~kg} \mathrm{t}^{-1}$ and $73.96 \mathrm{~kg} \mathrm{t}^{-1}$ and highest value of $94.71 \mathrm{~kg} \mathrm{t}^{-1}$ and $86.00 \mathrm{~kg} \mathrm{t}^{-1}$, respectively. The cultivars CMSXS647 reached the minimum 56 days after flowering, thereby having the shortest PIU (7 days) and the lowest average $\left(72.28 \mathrm{~kg} \mathrm{t}^{-1}\right)$. These results show a longer PIU than those found in a study conducted by Fernandes et al. (2014) where the BRS 508 maintained sugar concentration greater than $80 \mathrm{~kg} \mathrm{t}^{-1}\left(140 \mathrm{~g} \mathrm{~L}^{-1}\right)$ for 42 days and reached a maximum value of $92.57 \mathrm{~kg} \mathrm{t}^{-1}\left(162 \mathrm{~g} \mathrm{~L}^{-1}\right)$. In this same study, BRS 511 showed a better performance, with the sugar levels peaking at $109 \mathrm{~kg} \mathrm{t}^{-1}\left(191 \mathrm{~g} \mathrm{~L}^{-1}\right)$ and a PIU of 44 days. In general, after 42 days of flowering, the sugar concentrations decreased for all genotypes studied.

\section{Ethanol production (EP)}

The major free sugars in the juice of sweet sorghum, as explained before, are glucose, fructose and sucrose. It is noteworthy that sweet sorghum has a higher amount of reducing sugars compared to sugarcane. However, there is no difference in the total quantities of soluble sugars and the technological parameters and analytical methods for quality control of sweet sorghum may be the same as the ones used for the sugarcane (Gomes; Rodrigues; Oliveira, 2011).

The levels of sugar found in sweet sorghum are between $15-21 \%$, values very close to those found in sugarcane. As sweet sorghum has a higher concentration of reducing sugars (glucose and fructose), one should be more careful during the production process of ethanol, because there may be a greater risk of contamination, taking into account that contaminating bacteria in the material prioritize reducing sugars during the fermentation process (Machado, 2011).

In the Figure 4 there are the curves for the production of ethanol in liters per tonne. As in TRS and RS curves, it is possible to see that there is an increase in production over time. According to (May et al., 2012a; Schaffert, 2011) the optimal values for ethanol production for sweet sorghum cultivars in Brazil should be above $60 \mathrm{Lt}^{-1}$. The cultivar BRS 508 stood out in the production, reaching the minimum value at $14 \mathrm{DAF}$ with $63.35 \mathrm{~L} \mathrm{t}^{-1}$, with a maximum of $90.4 \mathrm{~L} \mathrm{t}^{-1}$ at $42 \mathrm{DAF}$ and ending with $78.6 \mathrm{~L}$ $\mathrm{t}^{-1}$ at 63 DAF, maintaining a good production for 49 days.

The genotype CMSXS629 reached $63.24 \mathrm{~L} \mathrm{t}^{-1}$ at $28 \mathrm{DAF}$ with a peak production of $75.5 \mathrm{~L} \mathrm{t}^{-1}$ at $42 \mathrm{DAF}$ maintaining a satisfactory production for 35 days. Other important results were the XBWS80147 and XBWS80007 that maintained a satisfactory production for a period of 28 days, reaching $66.23 \mathrm{~L} \mathrm{t}^{-1}, 60.67 \mathrm{~L} \mathrm{t}^{-1}$ at $35 \mathrm{DAF}$, respectively. The cultivars BRS511 reached the minimum threshold at $42 \mathrm{DAF}$ with $65.29 \mathrm{~L} \mathrm{t}^{-1}$, maintaining the production for 21 days. The sugargraze reached $61.9 \mathrm{~L} \mathrm{t}^{-1}$ at

\section{Recoverable Sugars (RS)}

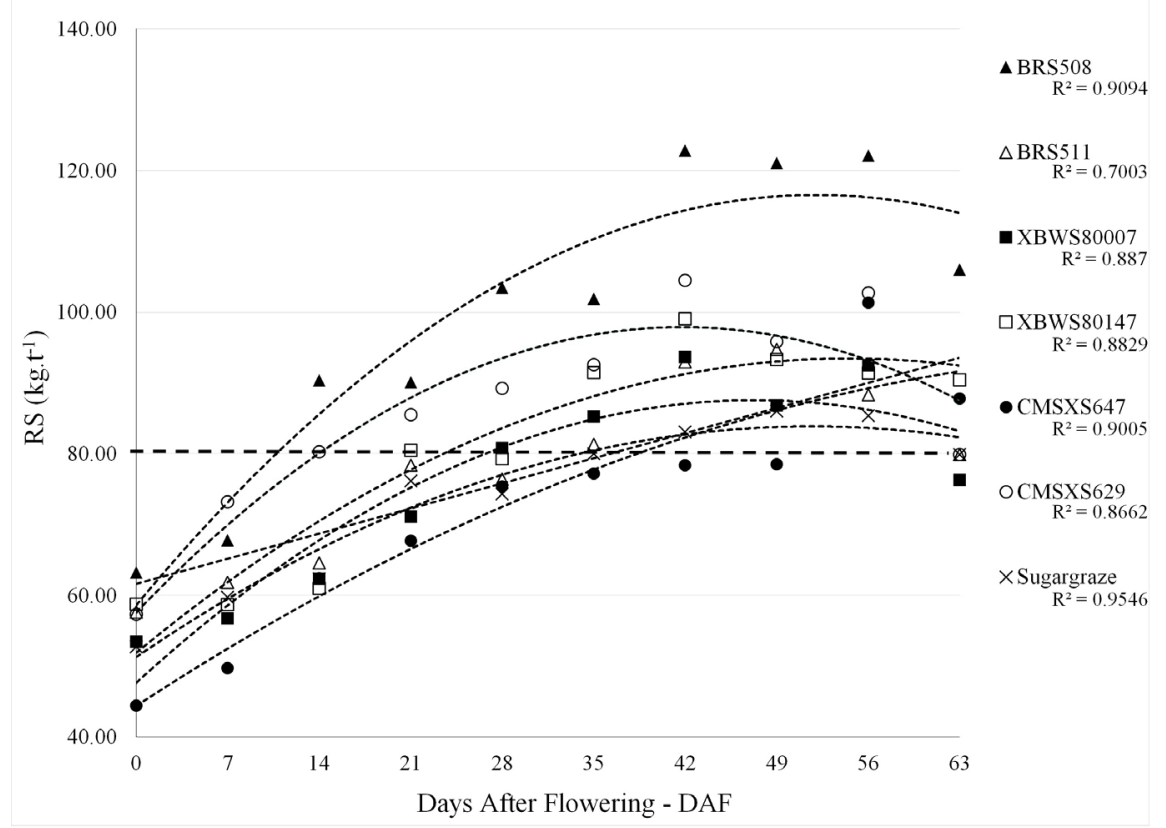

Figure 3: Curves of recoverable sugars (RS), in kg.t-1 of seven cultivars of sweet sorghum in ten harvest dates. 
$49 \mathrm{DAF}$ and maintained an average yield near this value until the end of the evaluations, totaling 14 days. The cultivar CMSXS647 reached the minimum limit only at $56 \mathrm{DAF}$, with $69.97 \mathrm{~L} \mathrm{t}^{-1}$.

These results show the potential of sweet sorghum for the production of ethanol and are higher than the amounts reported by Emygdio et al. (2011) studying the cultivar BR506, where it reached an average of 55 liters of ethanol per tonne of stalks. Similarly, Zhang et al. (2010) assessing the ethanol potential of sweet sorghum in China by ArcGIS methods obtained an average ethanol yield of approximately $62.5 \mathrm{~L} \mathrm{t}^{-1}$.

The adequate knowledge of the industrialization potential of each genotype is the most important factor in determining the amount and the planting moment of each of them. This planning is necessary in order to schedule the harvest and provide enough feedstock for a longer time for the full operation of the ethanol plant. In the Figure 5, it is presented the period of industrial use (PIU) for all genotypes, based on the $80 \mathrm{~kg} \mathrm{t}^{-1}$ threshold for recoverable sugars (RS) established by (May et al., 2012a; Schaffert, 2011). In this figure, it is possible to analyse the profiles of fresh mass production, accumulation of sugars and ethanol production of all cultivars and the relationship between the variables in each case. The adjustment of the data to the regression measured by the coefficient of determination was satisfactory for all genotypes analyzed.

\section{Ethanol Production (EP)}

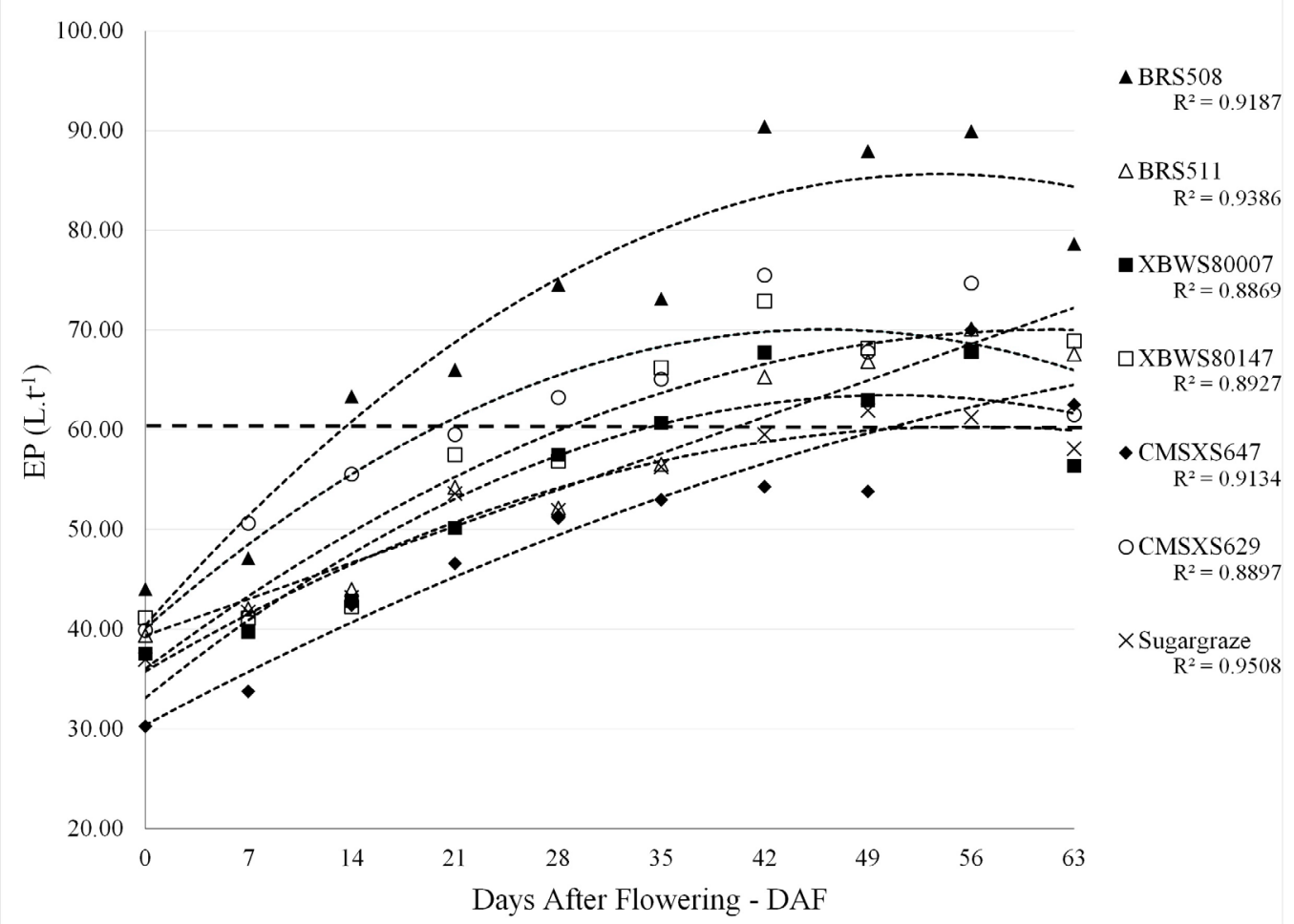

Figure 4: Curves of ethanol production (EP), in liters per tonne of seven cultivars of sweet sorghum in ten harvest dates. 

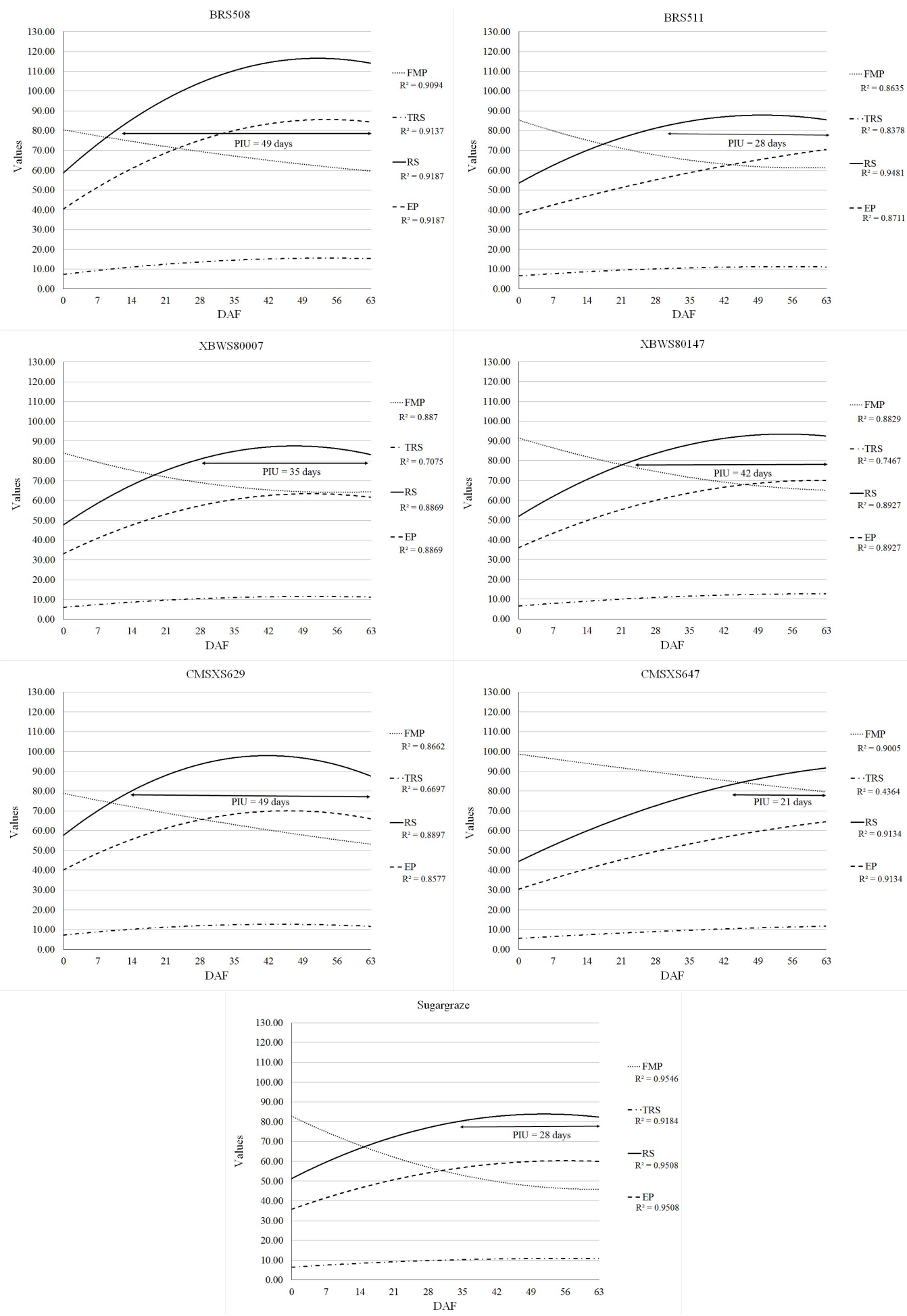

Figure 5: Maturation Curves of seven cultivars of sweet sorghum in ten harvest dates. PIU corresponding to RS above $80 \mathrm{~kg} \mathrm{t}^{-1}$. FMP (kilograms per tonne of biomass), TRS - Total reducing sugars (\%), RS - Total recoverable sugars (kilograms per tonne of biomass) and EP - ethanol production (liters per tonne of biomass). 


\section{CONCLUSIONS}

Analysing the maturation curves, it was found that there was an increase in the concentrations of total sugar in the juice and consequently a higher ethanol yield throughout the evaluations. It is worth mentioning that the cultivar BRS508 and the CMSXS629 showed a satisfactory performance and productivity with values similar to those obtained for sugarcane under the same operating conditions. These facts demonstrate the high potential of using sweet sorghum for the production of ethanol, and the capacity of these cultivars to sustain good yields for a long period of time may provide greater certainty in the harvest planning and usage of the feedstock in existing industrial facilities.

Despite the fact that the curves were variable for each genotype, it was possible to observe a trend in the analysis of the FMP, TRS, RS and EP, where the time of harvesting with the highest yield is found between 21 and 42 days after flowering.

\section{ACKNOWLEDGEMENTS}

The Authors acknowledge the financial support provided by the National Council for Scientific and Technological Development - CNPq and The Research Foundation of the State of Minas Gerais - FAPEMIG. The authors thank the Embrapa Milho e Sorgo and the Universidade Federal de São João del-Rei for additional support to conduct the experiments.

\section{REFERENCES}

ALBUQUERQUE, C. J. B. et al. Sorgo sacarino em diferentes arranjos de plantas e localidades de Minas Gerais, Brazil. Revista Brasileira de Milho e Sorgo, 11(1):69-85, 2012.

ALMODARES, A.; HADI, M. R.; AHMADPOUR, H. Sorghum stem yield and soluble carbohydrates under phonological stages and salinity levels. African Journal of Biotechnology, 7(22):4051-4055, 2008.

CHANNAPPAGOUDAR, B. B. et al. Assessment of sweet sorghum genotypes for cane yield, juice characters and sugar levels. Karnataka Journal of Agricultutral Sciences, 20(2):294-296, 2007.

COMPANHIA NACIONAL DE ABASTECIMENTO - CONAB. Acompanhamento da Safra Brasileira Cana-de-açúcar, Safra 2014/15, n.2. Brasília, DF: MAPA, 20p. 2014. Available in: <www.conab.gov.br>. Access in: April 10, 2015.

CONSELHO DOS PRODUTORES DE CANA-DE-AÇÚCAR, AÇÚCAR E ÁLCOOL DO ESTADO DE SÃO PAULO. Manual de
Instruções. Piracicaba-SP, 112p. 2006. Available in: <www. unicadata.com.br>. Acess in: January 20, 2015.

CRUZ, C. D. Programa Genes: Biometria. Viçosa: Editora UFV, 2006. 382p.

DAYAKAR, R. B. et al. Sweet Sorghum cane for biofuel production: A SWOT analysis in Indian context. Rajendranagar, Hyderabad, A P, India: National Research Center for Sorghum, 2004. 24p.

EMYGDIO, B. M. et al. Desempenho de cultivares de sorgo sacarino para a produção de etanol sob diferentes densidades de plantas. Pelotas: Embrapa Clima Temperado, Boletim de pesquisa e desenvolvimento - 156, 2011, 22p.

FERNANDES, A. C. Cálculos na Agroindústria da Cana-deaçúcar. Piracicaba: Sociedade dos Técnicos Açucareiros e Alcooleiros do Brasil, 2011. 416p.

FERNANDES, G. et al. Evaluation of potential ethanol production and nutrients for four varieties of sweet sorghum during maturation. Renewable Energy, 71:518-524. 2014.

GOMES, A.; RODRIGUES, D.; OLIVEIRA, P. Caracterização do sorgo para a produção de etanol. Agroenergia em Revista. 2(3):26, 2011.

GNANSOUNOU, E.; DAURIAT, A.; WYMAN, C. E. Refining sweet sorghum to ethanol and sugar: economic trade-offs in the context of North China. Bioresource Technology. 96:985-1002, 2005.

GUIYING, L. et al. A training manual for sweet sorghum. Bangkok, Thailand: FAO/CAAS/CAS. 2000. 134p.

MACHADO, C. M. M. Produção de etanol de sorgo sacarino. Agroenergia em Revista, 2(3):27-28, 2011.

MAY, A. et al. Sistema Embrapa de Produção Agroindustrial de Sorgo sacarino para Bioetanol Sistema BRS1G - Tecnologia Qualidade Embrapa. Sete Lagoas, MG: Embrapa Milho e Sorgo Documentos- 139, 2012a. 120p.

MAY, A. et al. Variedades de sorgo sacarino em diferentes espaçamentos e população de plantas. Revista Brasileira de Milho e Sorgo, 11(3):278-290, 2012b.

MURRAY, S. C. et al. Genetic improvement of sorghum as a biofuel feedstock: II. QTL for stem and leaf structural carbohydrates. Crop Science, 48(6):2180-2193, 2008.

PARRELLA, R. A. C. Melhoramento genético do sorgo sacarino. Agroenergia em Revista, 2(3): 8-9, 2011. 
PRASAD, S. et al. Ethanol production from sweet sorghum syrup for utilization as automotive fuel in India. Energy \& Fuels, 21(4):2415-2420, 2007.

RITTER, K. B. et al. Identification of QTL for sugar-related traits in a sweet $\times$ grain sorghum (Sorghum bicolor L. Moench) recombinant inbred population. Molecular Breeding, 22(3):367-384, 2008.

RYAN, J. G.; SPENCER, D. C. Future challenges and opportunities for agricultural R\&D in the semi-arid tropics. Andhra Pradesh, India: ICRISAT, 2001. 83p.

SCHAFFERT, R. E. et al. Metas de rendimento e qualidade de sorgo sacarino. Agroenergia em Revista, 2(3):47, 2011.

SILVA, R. N. Comparação de métodos para a determinação de açúcares redutores e totais em mel. Ciência e Tecnologia de Alimentos, 23(3):337-341, 2003.

TEIXEIRA, C. G. et al. Influência da época de corte sobre o teor de açúcares de colmos de sorgo sacarino.
Pesquisa Agropecuária Brasileira, 34(9):1601-1606, 1999.

TOMAZ, H. V. Q.; ASSIS, R. T. Sorgo sacarino - Rendimento extra na entressafra da cana-de-açúcar. Sustentabilidade e inovação no campo. 1:73-84, 2013.

WORLEY, J. W.; VAUGHAN, D. H.; CUNDIFF, J. S. Energy analysis of ethanol production from sweet sorghum. Bioresource Technology, 40(3):263-273, 1992.

WORTMANN, C. S. et al. Dryland performance of sweet sorghum and grain crops for biofuel in Nebraska. Agronomy Journal, 102(1):319-326, 2010.

ZEGADA-LIZARAZU, W.; MONTI, A. Are we ready to cultivate sweet sorghum as a bioenergy feedstock? A review on field management practices. Biomass and Bioenergy, 40:1-12, 2012.

ZHANG, C. et al. The productive potentials of sweet sorghum ethanol in China. Applied Energy, 87(7):2360-2368, 2010. 